IZA DP No. 7935

Job Satisfaction and Public Service Motivation

Lutz C. Kaiser

January 2014 


\title{
Job Satisfaction and Public Service Motivation
}

\author{
Lutz C. Kaiser \\ North Rhine-Westphalia University of Applied Sciences for Public Administration, \\ DIW and IZA
}

\author{
Discussion Paper No. 7935 \\ January 2014
}

IZA
P.O. Box 7240
53072 Bonn
Germany

Phone: +49-228-3894-0

Fax: +49-228-3894-180

E-mail: iza@iza.org

Any opinions expressed here are those of the author(s) and not those of IZA. Research published in this series may include views on policy, but the institute itself takes no institutional policy positions. The IZA research network is committed to the IZA Guiding Principles of Research Integrity.

The Institute for the Study of Labor (IZA) in Bonn is a local and virtual international research center and a place of communication between science, politics and business. IZA is an independent nonprofit organization supported by Deutsche Post Foundation. The center is associated with the University of Bonn and offers a stimulating research environment through its international network, workshops and conferences, data service, project support, research visits and doctoral program. IZA engages in (i) original and internationally competitive research in all fields of labor economics, (ii) development of policy concepts, and (iii) dissemination of research results and concepts to the interested public.

IZA Discussion Papers often represent preliminary work and are circulated to encourage discussion. Citation of such a paper should account for its provisional character. A revised version may be available directly from the author. 
IZA Discussion Paper No. 7935

January 2014

\section{ABSTRACT}

\section{Job Satisfaction and Public Service Motivation}

Based on a unique case study-dataset, the paper analyses job satisfaction and public service motivation in Germany. A special issue of the investigation is related to the evaluation of performance pay scales that were introduced some years ago to German public employees within the frame of fostering New Public Management. The findings display a general dominance of intrinsic motivators. Additionally, this kind of motivators plays an important role with regard to building up and keeping job satisfaction in the public sector. Further results display the transferability of competences, autonomy, regular appraisal interviews and productivity feedback as factors incorporating a positive significance in terms of job satisfaction.

JEL Classification: J28, J45

Keywords: job satisfaction, public service motivation, performance pay scales, HR-management

Corresponding author:

Lutz C. Kaiser

North Rhine-Westphalia University of

Applied Sciences for Public Administration

Thürmchenswall 48-54

50668 Köln

Germany

E-mail: lutz.kaiser@fhoev.nrw.de 


\section{Introduction}

Public service job satisfaction (PSJS) and Public service motivation (PSM) are topics that have broadly been discussed in the literature, respectively (e.g. Perry and Wise, 1990; Perry et al., 2010; Georgellis and Tabvuma, 2010; Rashid and Rashid, 2012; Bradley and Davis, 2003). The interrelation between PSM and PSJS, however, is rarely considered in scientific analyses so far. For an exception cf. Borzaga and Tortia, 2006 or Taylor and Westover, 2011.

The paper ties in with this status quo of research and utilizes a unique dataset to carry out a case study for investigating the interdependencies between PSJS and PSM. Both aspects are equally relevant for a future sustainable productivity of the public sector, as the forthcoming decades will be accompanied by a general boost in the demand for qualified manpower (Bonin et al., 2007). In conjunction with the upcoming demographic development, the public sector of the economy will increasingly compete against the private sector with regard to the remaining qualified workers. This is particularly an issue for the public sector, as it has to face an intensified cost pressure in terms of the deficit-debt adjustment (Vesper, 2012).

However, besides future prospects, what is the distinct importance of PSJS and PSM to the public sector? As public services incorporate their customers as comanufacturers of their service-product, it is essential that public employees experience job satisfaction and/or job motivation, since this 'primary satisfactionlevel' directly affects the 'secondary satisfaction level' of customers as comanufacturers (Loveman, 1998). Hence, PSJS and PSM are 'genuine capital equipment' for the public service sector. In the end, PSJS and PSM are correlates for an efficient spending of the money of taxpayers, as motivated and satisfied public employees aim at an effective perception of their work contents. Overall, PSJS and PSM are tools to develop a 'win-win-win situation' between public employees, public employers and citizens as tax payers. 


\section{Data Description}

The exploited data that refer to public service job satisfaction (in the following, 'PSJSdata'), were conducted by the author and arise from a case study of a communal public administration. The cross-sectional data were gathered in 2011 in a mediumsized city with some 60.000 inhabitants in the German county North RhineWestphalia ${ }^{1}$. In order to gain a high response rate, paper and pencil-questionnaires were handed over to the entire population of public employees $(N=874)$. Fortunately, with $57 \%$, the overall response rate was comparatively high $(\mathrm{n}=498)$. The total sample of 498 respondents includes a sub-sample of cleaning workers $(n=81)$. The particularity of this sub-sample is a lean sub-questionnaire that refers to a fewer number of questions and the choice between different languages (German or Turkish). Due to the two different versions of the questionnaires, long vs. lean, the sampled data refer either to $n=498$ or $n=417$ accounting for a questionnaire version with and a version without cleaning worker respondents. The descriptive and regression analyses presented here will account for the sample where the cleaning workers are excluded, since, for instance, information on the sources of job motivation was not gathered for this target population.

\section{Public Sector Motivation}

Public sector motivation (PSM) can be rated as 'an individual's predisposition to respond to motives grounded primarily or uniquely in public institutions and organizations' (Perry and Wise, 1990: 368). Hence, the configuration of the public sector as a societal instance of the democratic state and its government represents specific integrative values. These values are reflected by respective motivators that are offered at public workplaces. Employees interested in the exercise of these values may run through a sorting process during their demand for work. When entering the public workplace, employees identify and adapt the offered work values and workplace environment as a match with their intrinsic motivation (Perry and Vandenabeele, 2008).

\footnotetext{
${ }^{1}$ For the sake of legal data protection, the name of the city is not stated in this paper. However, for further detailed technical information on the utilized data, the author may be contacted.
} 
Therefore, it is essential to recognise what kinds of motivation-resources are drawn by public employees. The questionnaire of the PSJS-dataset defines seven default categories of job motivation (table 1). Due to the PSM-theory, it has to be expected that intrinsic motivators play a more pronounced role as opposed to extrinsic motivators like payment.

Table 1: Sources of job motivation $\%$

work content 72.2

job autonomy 69.8

loyal work environment 69.8

motivation via superior

customer contact

payment

performance pay

12.2

Source: PSJS-data, multiple answers possible, $n=417$, author's calculations.

Most frequently stated are 'work content', 'job autonomy', and 'loyal work environment'. However, other categories such as 'customer contact', match well with the assumptions of the PSM-theory, as these categories can be rated as adapted intrinsic motivators. Accordingly, rather extrinsic motivators, in particular performance pay, turn out to possess a marginal impact only.

Irrespective to the given items, the questionnaire additionally allows for an individual stating of 'other sources of work motivation'. In terms of further sources of job motivation, again most of the other stated items are related to intrinsic motivation, like 'mutual appraisal and acceptance of colleagues', 'work with children', 'responsibility against target group of customers', 'positive feedback of customers', or 'personal responsibility'.

As the questionnaire construction allows for multiple answers with regard to different sources of job motivation, table 2 describes the number of job motivation resources. About a quarter of the respondents possess three different job motivators. $1.2 \%$ claim to have no job motivators at all. On the other side of the distribution, less than 1 $\%$ indicate to utilize seven, eight or nine different job motivators, respectively. 
Table 2: Number of job motivation resources

$\%$

$\begin{array}{lr}0 & 1.2 \\ 1 & 9.6 \\ 2 & 17.5 \\ 3 & 26.1 \\ 4 & 20.1 \\ 5 & 17.0 \\ 6 & 6.7 \\ 7 & 0.7 \\ 8 & 0.7 \\ 9 & 0.2\end{array}$

Source: PSJS-data, $n=417$, author's calculations.

To gather more detailed information with regard to job motivation the sources of motivation were cross-tabulated against age. Within this focus it is striking that with rising age, payment and performance pay become less important for public employees (table 3). On the other hand, the impact of job autonomy and customer contact gain as job motivators with rising tenure.

Table 3: Sources of job motivation by age group (in \%, allowing for multiple answers)

\begin{tabular}{ccccccccr}
\hline age group & $\begin{array}{c}\text { work } \\
\text { content }\end{array}$ & $\begin{array}{c}\text { job } \\
\text { autonomy }\end{array}$ & $\begin{array}{c}\text { customer } \\
\text { contact }\end{array}$ & $\begin{array}{c}\text { motivation } \\
\text { via } \\
\text { superior }\end{array}$ & $\begin{array}{c}\text { loyal work } \\
\text { environ- } \\
\text { ment }\end{array}$ & payment & $\begin{array}{c}\text { perfor- } \\
\text { mance pay }\end{array}$ & n \\
\hline$<25$ & 92.3 & 61.5 & 23.1 & 46.2 & 84.6 & 46.2 & 15.4 & 13 \\
$25-34$ & 75.0 & 54.4 & 29.4 & 50.0 & 80.9 & 39.7 & 17.7 & 68 \\
$35-44$ & 71.3 & 71.3 & 31.5 & 47.2 & 74.1 & 40.7 & 16.7 & 108 \\
$45-54$ & 72.7 & 74.7 & 37.7 & 45.5 & 68.8 & 29.9 & 9.1 & 154 \\
$55+$ & 67.2 & 71.9 & 39.1 & 23.4 & 51.6 & 21.9 & 6.3 & 64 \\
\hline Total & 72.5 & 69.5 & 34.4 & 43.2 & 70.0 & 33.7 & 12.3 & 407 \\
\hline
\end{tabular}

Source: PSJS-data, author's calculations.

These findings are again compatible with the assumptions of the PSM-theory and can be rated as an allusion to the adaptation process towards intrinsic motivators when time goes by. Conclusively, the magnitude of more extrinsic motivators like motivation via superior as well as loyal work environment tends to fade out. 


\section{Performance Pay Scales}

Performance pay scales were introduced in the German public sector in 2005 within the frame of implementing a completely new payment scheme (the so-called TVöD). At the beginning of the new payment scheme, the share of performance pay related to gross income as of the prior year was $1.25 \%$. In a stepwise process, the proportion should rise within the next years up to $8 \%$. Nevertheless, the expenses of the implementation and accentuation are cross-subsidised by a cut in other fringebenefits, such as the Christmas bonus (Tondorf, 2007).

The PSJS-data allow to analysing performance pay scales from different angles. The survey participants were asked if they generally support the idea of introducing performance pay scales (table 4). About three-fourths of the respondents $(73.9 \%)$ supported this idea with no significant differences between men and women worth to be mentioned.

Table 4: General acceptance of performance pay scales by sex (in \%)

\begin{tabular}{cccc}
\hline & yes & no & $\mathrm{n}$ \\
\hline women & 74.6 & 25.4 & 232 \\
men & 73.1 & 27.0 & 167 \\
\hline Total & 73.9 & 26.1 & 399 \\
\hline
\end{tabular}

Source: PSJS-data, author's calculations.

Furthermore the questionnaire contains items with regard to the evaluation of the concrete implementation of the performance pay scale at the workplace. At this point, obvious discrepancies between the general acceptance and the practical implementation occurred (table 5). $47.3 \%$ of the respondents indicated as not being satisfied and $34.5 \%$ mentioned to partly agree with the practical approach. Only 18.2 $\%$ stated to be satisfied. Furthermore, male public workers tend to be less satisfied with the on-site operation as compared to their female counterparts, since some 50 $\%$ of men were dissatisfied as opposed to women with $45 \%$. Similar differences became obvious regarding the type of contract (full/part time). Full-timers are more dissatisfied (48.9\%) compared to part-timers (41.8\%). However, the displayed difference may partially be due to the fact that more women work part-time as 
compared to men. Overall, the findings suggest men to expect a higher successful impact of performance pay scales in the public sector.

Table 5: Satisfaction with the practical implementation of performance pay scales (in \%)

\begin{tabular}{lcccc}
\hline & yes & no & partly & $\mathrm{n}$ \\
\hline women & 17.7 & 45.1 & 37.2 & 226 \\
men & 18.8 & 50.3 & 30.9 & 165 \\
\hline Total & 18.2 & 47.3 & 34.5 & 391 \\
\hline full-time & 18.8 & 48.9 & 32.3 & 276 \\
part-time & 18.4 & 41.8 & 39.8 & 103 \\
\hline Total & 18.7 & 47.0 & 34.3 & 379 \\
\hline
\end{tabular}

Source: PSJS-data, author's calculations.

\section{Public Service Job Satisfaction and Public Service Motivation}

PSM plays a crucial role for job satisfaction in the public sector (Pandey and Stazyk, 2008). Which rationale is behind this statement? If present on the job or in public organisations, PSM may accelerate public service job satisfaction (PSJS), since public worker preferences and incentive structures can be described as 'complex and distinctive structures who are not predominately driven by monetary re-numeration' (Borzaga and Tortia, 2006: 226). Hence, jobs in the public sector should offer numerous opportunities for public workers to realise their typical motives. Government workers, whose motives match with the successful production of the public sector, i.e. producing and distributing public goods, are likely to be satisfied with their jobs. Similarly, a positive work environment and collegial job atmosphere should reflect the needs and motives of public workers and enhance their PSJS.

Besides job-satisfaction, the PSJS-data contain various other segments of subjective well-being categories like regarding health or in terms of income. The entire set of the related questions was designed according to the questionnaire setting of the German Socio-economic Panel (SOEP). If a survey participant is totally dissatisfied, one should tick ' 0 ', if a respondent is fully satisfied, a '10' has to be marked. ${ }^{2}$ For gauging satisfaction levels in between codes ' 1 ' to ' 9 ' were available.

\footnotetext{
${ }^{2}$ The background of this scale is described by Wagner (2007).
} 
Table 6 summarizes the results of the different spheres of satisfaction. The utilised scale would display a numerical value of 5 on average, if an equal number of respondents are satisfied and not satisfied along the range of the scale ' 0 ' to ' 10 '. Given this hypothetical average, the empirical results show that the respondents are only slightly above-average satisfied with their individual- (5.62) and household income (5.89). This finding reflects the comparatively 'low income capacity' of public sector jobs that may result in a relatively low satisfaction with income among the respondents. Higher average results were reported for health- and child caresatisfaction. Job-satisfaction averaged at 6.80 , but even higher average satisfaction levels can be found with regard to honorary posts (7.20), leisure (7.47), family- (8.06) and housing situation (8.10). An averaging of all results for all satisfaction categories would yields to an average of 6.92. Keeping this average in mind, it becomes obvious that the values for private related categories (honorary post, leisure, family and housing) exceed the remaining values for job related categories. In principle, 'two worlds of satisfaction' emerge, one of a private- and another of a job related nature, although it has to be admitted that health may related to both, the private and the jobsphere.

Table 6: Spheres of satisfaction

\begin{tabular}{lccc}
\hline \hline satisfaction category & mean & std.-dev. & $\mathrm{n}$ \\
\hline housing situation & 8.10 & 2.21 & 403 \\
family situation & 8.06 & 2.37 & 349 \\
leisure & 7.47 & 2.30 & 402 \\
honorary post & 7.20 & 2.63 & 165 \\
job & 6.80 & 2.29 & 408 \\
health & 6.64 & 2.44 & 407 \\
child care & 6.51 & 2.87 & 85 \\
household income & 5.89 & 2.44 & 402 \\
individual income & 5.62 & 2.45 & 402 \\
\hline & & reporting all answers in all categories summarised \\
\hline
\end{tabular}

Source: PSJS-data, author's calculations. 
The following refers to potential determinants of PSJS utilising the PSJS-data. In addition, the link between motivation and job satisfaction will be investigated. The utilized ordered probit-model is a latent variable-model with a monotonic ordering of the qualitative responses. The job satisfaction scale from 0 to 10 means nothing in terms of their values, as it is just an ordering to define the lowest to highest value. Hence, a job satisfaction valued with ' 8 ' is not twice as high as job satisfaction rated with '4'. Therefore, the latent variable is an index of self-reported job satisfaction. As a non-linear model, the coefficients of the ordered probit-model cannot directly be interpreted as quantitative effects, but rather as positive or negative (significant or insignificant) impacts on job satisfaction ${ }^{3}$.

The exogenous variables of the model are chosen in sight of the specific expectation and motivation of public workers. If these expectations are met, the reward should be materialized in a job satisfaction surplus.

The self-determination theory explicitly applies to this approach and has '(...) detailed the processes through which extrinsic motivation can become autonomous, and research suggests that intrinsic motivation (based in interest) and autonomous extrinsic motivation (based in importance) are both related to performance, satisfaction, trust, and well-being in the workplace' (Gagné and Deci, 2005: 356).

Extrinsic motivation is mainly due to the setting of leadership in organizations. The transactional leadership-approach aims to '(s)et goals, articulate explicit agreements regarding what the leader expects from organizational members and how they will be rewarded for their efforts and commitment, and provide constructive feedback to keep everybody on task' (Vera and Crossan, 2004: 224).

The data allow to partially modulating these aspects. First, the regression model controls for the different sources of motivation and for potential divergences between the general vs. the practical assessment of performance pay scales. Second, an

\footnotetext{
${ }^{3}$ A detailed description of the ordered probit-model is offered by Long, 1997: 115-147.

${ }^{4}$ This kind of leadership may be more suitable for the public sector, in particular for public administrations, as compared to the somewhat more 'creative' transformational leadership-approach. For the setting of this leadership, cf. Bass and Riggo (2006).
} 
individually self-estimated judgment of the working atmosphere is included in the regression.

Self-determination as such is considered by the transferability of competences and by autonomy. The transactional leadership and its potential determination on job satisfaction is modulated by several variables (information transmission by superior, briefing frequency, appraisal interview, productivity feedback, feedback in case of mistakes, HR-management quality of superior). Last but not least it is important to control for socio-demographic differences among the respondents like age, working hours and type of contract (cf. annex table A-1 for the definition of these variables).

The summary statistics of the ordered probit-regression display a mean job satisfaction value of 6.7 (table 7). Again, the job motivators 'job autonomy', 'work content' and 'loyal work environment' display the most frequent occurrences. Off less importance are payment and performance pay scales as work motivators. However, more than $50 \%$ of the sample respondents have to face a divergence between their general support of performance pay scales and the practical implementation of this fringe benefit at their workplace.

A positive work environment is experienced by some $42 \%$ of the public workers. However, circa $39 \%$ report no transferability of their competences and about $14 \%$ claim to possess no autonomy. Some $34 \%$ indicate an information transmission via their superiors, but $21 \%$ state none or rare briefing frequency. Similar is true regarding appraisal interviews (26\%). Moreover, $50 \%$ receive no positive feedback in case of proper working results, whereas $27 \%$ experience no feedback in terms of mistakes. About $14 \%$ evaluate the HR-management quality of their superior as insufficient.

The socio-economic features of this sample display a surplus of female workers in the data. More than two-third are assignable towards the age-band of 35 to 54 years of age, $27 \%$ are working on a part-time basis and $11 \%$ possess a temporary contract. 
Table 7: Summary statistics of the ordered probit-regression

\begin{tabular}{llccc}
\hline Variable & mean & std.-dev. & min & max \\
\hline job satisfaction & 6.73 & 2.33 & 0 & 10 \\
\hline motive force: work content & .7110 & .4545 & 0 & 1 \\
motive force: job autonomy & .7222 & .4486 & 0 & 1 \\
motive force: customer contact & .3304 & .4710 & 0 & 1 \\
motive force: motivation via superior & .4414 & .4973 & 0 & 1 \\
motive force: loyal work environment & .6944 & .4614 & 0 & 1 \\
motive force: payment & .3519 & .4783 & 0 & 1 \\
motive force: performance pay-scale & .1420 & .3496 & 0 & 1 \\
no motive force at all & .0123 & .1106 & 0 & 1 \\
\hline general/practical gap re. perfor. pay scale & .5556 & .4977 & 0 & 1 \\
\hline positive working atmosphere & .4198 & 4943 & 0 & 1 \\
no transferability of working competences & .3858 & .4875 & 0 & 1 \\
no autonomy on the job & .1420 & .3496 & 0 & 1 \\
\hline information transmission via superior & .3426 & .4753 & 0 & 1 \\
briefing frequency: none/rare & .2130 & .4100 & 0 & 1 \\
appraisal interview: none/rare & .2623 & .4406 & 0 & 1 \\
no feedback in case of productivity & .5000 & .5008 & 0 & 1 \\
no feedback in case of mistakes & .2716 & .4455 & 0 & 1 \\
bad HR-management of superior & .1420 & .3496 & 0 & 1 \\
\hline sex: male & .4167 & .4938 & 0 & 1 \\
age < 25 & .0278 & .1646 & 0 & 1 \\
age 25 - 34 & .1698 & .3760 & 0 & 1 \\
age 35 - 44 & .2623 & .4406 & 0 & 1 \\
age 45 - 54 & .3765 & .4853 & 0 & 1 \\
age 55 + & .1512 & .3588 & 0 & 1 \\
part-time & .2716 & .4455 & 0 & 1 \\
temporary contract & .1111 & .3148 & 0 & 1 \\
\hline Source: & & & & 1 \\
\hline
\end{tabular}

Source: PSJS-data, author's calculations $(n=324)$.

With regard to job satisfaction, it has to be expected that intrinsic motivators show up with a statistical significance rather than extrinsic motivators like payment. Accordingly, the results display the motivator 'work content' and 'customer contact' to be positively correlated with job satisfaction (table 8). Those public workers who can utilize these intrinsic motivators gain in job satisfaction. The remaining job motivators have no statistical significant impact. However, these variables partially show the expected sign, like 'motivation via superior' and 'payment' (positive) or 'general/practical gap regarding performance pay scale' (negative). 
Table 8: Results of the ordered probit-regression

\begin{tabular}{lcc}
\hline & coefficient & std. error \\
\hline motivator: work content & $0.381^{* * *}$ & $(0.135)$ \\
motivator: job autonomy & 0.139 & $(0.137)$ \\
motivator: customer contact & $0.291^{* *}$ & $(0.131)$ \\
motivator: motivation via superior & 0.040 & $(0.131)$ \\
motivator: loyal work environment & -0.095 & $(0.142)$ \\
motivator: payment & 0.103 & $(0.132)$ \\
motivator: performance pay-scale & -0.102 & $(0.177)$ \\
\hline general / practical gap re. performance pay scale & -0.168 & $(0.121)$ \\
\hline positive working atmosphere & $0.792^{* * *}$ & $(0.138)$ \\
no transferability of working competences & $-0.525^{* * *}$ & $(0.135)$ \\
no autonomy on the job & $-0.513^{* * *}$ & $(0.187)$ \\
\hline information transmission via superior & 0.128 & $(0.148)$ \\
briefing frequency: none/rare & -0.068 & $(0.148)$ \\
appraisal interview: none/rare & $-0.305 * *$ & $(0.141)$ \\
no feedback in case of productivity & $-0.490 * * *$ & $(0.144)$ \\
no feedback in case of mistakes & 0.167 & $(0.140)$ \\
bad HR-management of superior & -0.244 & $(0.194)$ \\
\hline sex: male & 0.148 & $(0.143)$ \\
age 25 - 34 & -0.112 & $(0.325)$ \\
age 35 - 44 & -0.039 & $(0.327)$ \\
age 45 - 54 & -0.167 & $(0.321)$ \\
age $55+$ & -0.162 & $(0.344)$ \\
part-time & 0.126 & $(0.151)$ \\
temporary contract & 0.186 & $(0.211)$ \\
\hline
\end{tabular}

$\log$ likelihood $(0)=-695.1, \log$ likelihood $=-605.3 ; \mathrm{LR} \mathrm{chi}^{2}(24)=179,6 ; \mathrm{Prob}>\mathrm{chi}^{2}=.0000 ;$ Pseudo $\mathrm{R}^{2}=.1292$ Ordered probit-model. Statistical significance of coefficients: ${ }^{* \star *}$ high $(p<0.01),{ }^{* *}$ medium $(p<0.05),{ }^{*}$ low $(p<0.1)$ Source: PSJS-data, author's calculations $(n=324)$.

A positive working atmosphere and self-determination, reciprocally operationalized by 'no transferability of working competences' and 'no autonomy', clearly have an impact on job satisfaction in the public sector. These three factors exhibit a high (statistical) impact, both in case of a positive working atmosphere and if one lack the transferability of competences and/or autonomy. In terms of various aspects of the transactional leadership, the omission of appraisal interviews and the failure to give feedback in terms of productivity result in a discount of job satisfaction. 


\section{Conclusion}

The findings with regard to public service job satisfaction and public service motivation display a general dominance of intrinsic motivation that may have induced public workers to choose public sector jobs. Furthermore, specific intrinsic motivators, like work content and customer contact, are utilized to gain job satisfaction.

These findings suggest public employers to facilitate their public workers exercising intrinsic motivators. This rationale can be rated as a kind of 'give way sign' for fostering intrinsic rather than extrinsic motivators in the public sector. This may also imply not to crowding out intrinsic motivators against extrinsic motivators (cf. Georgellis et al. 2011). However, with implementing performance pay scales in the public sector to foster New Public Management, extrinsic rewards are on the rise. These kinds of extrinsic tools should be handled with care, as payment is also a latent motivator in the public sector.

Further results strongly recommend to putting up-to-date human resource management tools into action. Notably, a modern toolbox of HR-management should include devices to allow for self-determination at the workplace, like the transferability of competences and autonomy. The findings of this study also claim that none or rare appraisal interviews and/or no feedback in terms of productivity result in a significant decline in job satisfaction of the concerned workers.

Are (adapted) intrinsic motivations of public workers a 'gratis perpetual mobile machine' for public organisations, i.e. is job motivation handed in for free by the public workforce? The answer could be 'yes and no'. What are the potential practical consequences for the public sector with regard to this twofold answer?

'Yes' in terms of a potential natural positive selection process of public workers with regard to intrinsic motivation. 'No' due to the necessity to develop a modern human resource management e.g. by a substantial further training of superiors and employees. 'No' again, since in particular guaranteeing a positive working atmosphere is not for free, e.g. by means of a cost intensive sufficient ratio of public workers against customers (service quantity). 
A steady enhancement of public service quality is likewise not in vain, but an indispensable need to create a platform for exercising intrinsic job motivation in the public sector. The latter also includes a further development of public sector service marketing (Kaiser 2012). Within this suggested frame of public service HRmanagement, public sector organizations may target at a win-win-win situation between public employers, public employees and citizens as tax payers. 


\section{References}

Bass, B. M. and Riggio, R. E. (2006), Transformational Leadership, Lawrence Erlbaum Associates, Mahwah, NJ.

Bonin, H., Schneider, M., Quinke, H. and Arens, T. (2007), Zukunft von Bildung und Arbeit. Perspektiven von Arbeitskräftebedarf und -angebot bis 2020, Institute for the Study of Labor, Bonn, IZA Research Report, 9.

Borzaga, C. and Tortia, E. (2006), "Worker motivations, job satisfaction and nonprofit social services", Nonprofit and Voluntary Sector Quarterly, Vol. 35 No. 2, pp. 225 248.

Bradley E.W. and Davis, B.S. (2013), "Job satisfaction in the public sector: The role of the work environment", The American Review of Public Administration, Vol. 33 No. 3, pp. 70-90.

Gagné, M. and Deci, E. L. (2005), "Self-determination theory and work motivation", Journal of Organizational Behavior, Vol. 26 No. 3, pp. 331-362.

Georgellis, Y. and Tabvuma, V. (2010), "Does public service motivation adapt?", Kyklos, Vol. 63 No. 2, pp. 176-191.

Georgellis, Y., lossa, E. and Tabvuma, V. (2011), "Crowding out intrinsic motivation in the public sector", Journal of Public Administration Research and Theory, Vol. 21 No. 3, pp. 473-493.

Kaiser, L. C. (2012), "Mehr Marketing im Sozialleistungsbereich“, Public Marketing, No. 12 , pp. $26-29$.

Long, S. J. (1997), Regression models for categorical and limited dependent variables, Sage, London. 
Loveman, G. (1998), "Employee satisfaction, customer loyalty and financial performance", Journal of Service Research, Vol. 1 No. 1, pp. 18-31.

Pandey, S. K. and Stazyk, E. C. (2008), "Antecedents and correlates of public service motivation" in Perry, J. L. and Hondeghem, A. (Eds.), Motivation in public management: The call of public service, Oxford University Press, Oxford, pp. 101117.

Perry, J. L. and Wise, L. R. (1990), "The motivational bases of public service", Public Administration Review, Vol. 50 No. 3, pp. 367-373.

Perry, J., Hondeghem, L. and Wise, L. R. (2010), "Revisiting the motivational bases of public service: Twenty years of research and an agenda for the future", Public Administration Review, Vol. 70 No. 5, pp. 681-690.

Perry, J. L. and Vandenabeele, W. (2008), "Behavioral dynamics: Institutions, identities, and self-regulation" in Perry, J. L. and Hondeghem, A. (Eds.), Motivation in public management: The call of public service, Oxford University Press, Oxford, pp. 56-73.

Rashid, S. and Rashid, U. (2012),"Work motivation differences between public and private sector", American International Journal of Social Science, Vol. 1 No. 2, pp. 24-33.

Taylor, J. and Westover, J. H. (2011), "Job Satisfaction in the public service: The effects of public service motivation, workplace attributes and work relations", Public Management Review, Vol. 13 No. 5, pp. 731-753.

Tondorf, K. (2007), Tarifliche Leistungsentgelte: Chance oder Bürde?, Edition Sigma, Berlin.

Vera, D. and Crossan, M. (2004), "Strategic leadership and organizational learning", Academy of Management Review, Vol. 29 No. 2, pp. 222-240. 
Vesper, D. (2012), Finanzpolitische Entwicklungstendenzen und Perspektiven des öffentlichen Dienstes in Deutschland, Institut für Makroökonomie und Konjunkturforschung, Düsseldorf, IMK Study, 25.

Wagner, G. G. (2007), „Wie die 11er-Skala in das SOEP kam - Ein Beitrag zu den Problemen und Möglichkeiten multidisziplinärer Forschung und zugleich eine Fußnote zum Design der SOEP-Stichprobe“, in Schwarze, J., Räbiger, J. and Thiede, R. (Eds.), Arbeitsmarkt- und Sozialpolitikforschung im Wandel - Festschrift für Christof Helberger zum 65. Geburtstag, Dr. Kovac, Hamburg, pp. 40-62. 
Table A-1: Variable definition, ordered probit-model

\begin{tabular}{ll}
\hline job satisfaction & self-estimated job satisfaction (scale 0-10) \\
\hline motivator: work content & $=1$ if work content motivates \\
motivator: job autonomy & $=1$ if job autonomy motivates \\
motivator: customer contact & $=1$ if customer contact motivates \\
motivator: motivation via superior & $=1$ if motivation via superior motivates \\
motivator: loyal work environment & $=1$ if a loyal work environment motivates \\
motivator: payment & $=1$ if payment motivates \\
motivator: performance pay scale & $=1$ if motivation by performance pay scale \\
no motivator at all (reference category) & $=1$ if respondent possess no job motivators at all \\
\hline general/practical gap regarding & $=1$ if performance pay scales are supported \\
performance pay scale & $=1$ but practical implementation is criticized \\
\hline positive working atmosphere & $=1$ if working competences are irrelevant for job \\
no transferability of working competences & $=1$ if employee has no autonomy on the job \\
no autonomy & $=1$ if work-rel. information is transferred by superior \\
\hline information transmission via superior & $=1$ if no or rare briefing frequency \\
briefing frequency: none/rare & $=1$ if no or rare frequency of appraisal interviews \\
appraisal interview: none/rare & $=1$ if lack in feedback in case of productive work \\
no feedback in case of productivity & $=1$ if no feedback in case of mistakes \\
no feedback in case of mistakes & $=1$ if bad assessment of HR-quality of superior \\
bad HR-management quality of superior & $=1$ if sex is male \\
\hline sex: male & $=1$ if respondent is less than 25 yrs. of age \\
age $<25$ (reference category) & $=1$ if respondent is between $25-34$ yrs. of age \\
age $25-34$ & $=1$ if respondent is between $35-44$ yrs. of age \\
age $35-44$ & $=1$ if respondent is between $45-54$ yrs. of age \\
age $45-54$ & $=1$ if respondent is at least 55 years of age \\
age $55+$ & $=1$ if working time is part-time \\
part-time & $=1$ if working contract is temporary \\
temporary contract &
\end{tabular}

Source: PSJS-data, author's compilation. 